\title{
Extrapolating nutritional potentials of ensiled wild sunflower (Tithonia diversifolia) leaf meal: proximate composition and functional properties
}

\author{
Ayodeji Oludare FASUYI* and Prince OKEKE \\ Department of Animal Production and Health Sciences, Ekiti State University, P. M. B. 5363, Ado-Ekiti, \\ Ekiti State, Nigeria. \\ *Corresponding author; E-mail: dejifasuyi@yahoo.com
}

\begin{abstract}
Tithonia diversifolia leaf was harvested, processed and ensiled for the purpose of determining the proximate and some functional properties. On proximate analyses, ensiled Tithonia diversifolia leaf meal (eTDLM) had crude protein value of $20.0 \% \pm 3.61$; crude fiber $19.0 \% \pm 0.01$; ether extract (lipid content) $4.0 \% \pm 0.05$ and ash content was an average of $16.7 \% \pm 0.01$. Nitrogen free extract (carbohydrate) was relatively high at $26.0 \% \pm 0.01$, while moisture content averaged $11.8 \% \pm 0.01$. Water absorption capacity (WAC) averaged $310.0 \% \pm 1.0$, while the fat absorption capacity (FAC) was $354.5 \% \pm 0.1$. Mean fat emulsion capacity and emulsion stability of the leaf meal were $42.5 \% \pm 0.07$ and $57.5 \% \pm 0.1$, respectively. Bulk density averaged 0.8 $\mathrm{g} / \mathrm{ml}$ while foaming capacity (FC), foaming stability (FS) and least gelation concentration (LGC) averaged $11.0 \% \pm 0.07,3.0 \mathrm{~cm} \pm 0.7$ and $8.0 \% \pm 0.1$, respectively. Comparison of the proximate composition and functional properties of eTDLM against known food agents established the potential usefulness of eTDLM in food systems and as a probable alternative feed ingredient in monogastric protein feed supplementation.

(C) 2014 International Formulae Group. All rights reserved.
\end{abstract}

Keywords: Anaerobic biodegradation, preliminary nutritional study, ensiled Tithonia diversifolia leaf meal.

\section{INTRODUCTION}

There are many trees and herbs as well as forages in the tropics that have the potential of being sources of high quality food and protein. However, there are limited information about these plant resources and as such are often not well utilized. Many of these plant resources are also known to contain antinutrients which inhibit the release of the potential nutrients contained in them (Fasuyi et al., 2010). Hence more research works are needed to assess the opportunities offered by these plant products and constraints to their utilization. One of such plants that grows wild in the upland region of the tropics and most tropical parts of Africa and which scanty information exists of its nutritional potentials is Tithonia diversifolia.

Tithonia diversifolia commonly known as Mexican sunflower was probably introduced into West Africa as an ornamental plant. It has been observed to be widely spread in Nigeria where it is found growing uncultivated on abandoned/waste lands, along major roads and waterways and on cultivated farmlands (Fasuyi et al., 2010). Tithonia has been a subject of research interest because of the relatively high nutrient concentrations found in its biomass and because of its ability to extract relatively high amounts of nutrients 
from the soil. Tithonia diversifolia leaf with a crude protein content of $18.9 \%$, crude fiber content of $11.0 \%$, ether extract of about $5.5 \%$ and mineral ash of about $13.2 \%$ (Olayeni et al., 2006) would be a potential source and supplement of satisfactory quality protein in food systems and livestock feed formulation. However, it may be necessary to employ specific processing methods to eliminate or at least reduce the anti-nutritional factors contained in its biomass which may inhibit the utilisation of protein and other nutrients contained in it. Although the presence of these anti-nutritional factors is always in trace quantities, they have been established to play significant roles in the nutritional quality of foods. However, many food processing techniques have been highlighted as possible means of reducing or eliminating the antinutrient levels in plant food source to innocuous levels that can be tolerated by animals particularly in monogastric (Fasuyi and Aletor, 2005). Ensiling as a processing technique helps to breakdown the fiber content of the crop material, reduces anti nutritional factor and increases digestibility as well as dry matter content. Ensiling involves the breaking down of carbohydrates into lactic acid and protein into amino acid, amines and ammonia (Pham SyTiep et al., 2006). It increases digestibility of crude protein by breaking down linkages between protein and fiber in the ensiled material. It also increases dry matter and lactic acid contents.

This study is targeted at determining the nutritional potentials of ensiled Tithonia diversifolia leaf meal using parameters emanating from proximate analyses and functional properties.

\section{MATERIALS AND METHODS}

Location of the experimental site

Harvesting of the leaves was done within Ekiti State University community in Ado-Ekiti, a town in the South-west Nigeria. Ado-Ekiti is situated in the rain forest zone on latitude $7^{\circ} 40^{\prime}$ North of the equator and longitude $5^{\circ} \quad 15^{\prime}$ East of the Greenwich Meridian with ambient temperature, $25{ }^{0} \mathrm{C}-37$ ${ }^{0} \mathrm{C}$; relative humidity, $70 \%$; wind, $\mathrm{SSW}$ at $11 \mathrm{mph}(18 \mathrm{~km} / \mathrm{h})$; barometric pressure, 29.68' $\mathrm{Hg}(\mathrm{F})$.

\section{Preparation of test ingredient}

Samples of fresh Tithonia diversifolia leaves were harvested from a maturing Tithonia diversifolia plant with a sharp kitchen knife. The harvesting was carried out from the top to the middle of the plant when the first inflorescence had opened in $60-80 \%$ of the Tithonia plant. Harvesting of the leaves was done in the premises of Ekiti State University, Ado-Ekiti. The leaves were chopped into pieces of about $2-3 \mathrm{~cm}$ and ensiled in a plastic container of about $120 \mathrm{~kg}$ capacity using sugarcane molasses as the silage additive in a percentage of $4 \%$ to the total weight (wet basis) of the chopped leaves in the container. The plastic container holding the ensiled leaves of Tithonia diversifolia was properly sealed and carefully closed to prevent any air contamination and kept in a safe environment to prevent physical damages or alterations.

The ensiling process was carried out for a period of 21 days. Samples of the ensiled TDLM (eTDLM) were taken out of the ensiling container and spread in the sun on a polythene bag and allowed to dry for a period of 4 days. The sun-drying of the wet eTDLM was monitored to be uniform by frequently turning the material to ensure even-drying of the whole material to about $10-12 \%$ moisture content. After drying had taken place, the dried eTDLM was finely ground and several samples parcelled into air-tight polythene bags for further laboratory analyses.

\section{Proximate composition of ensiled Tithonia diversifolia leaf meal, eTDLM}

The proximate composition of ensiled Tithonia diversifolia leaf meal was determined by AOAC (2010) method. 
Triplicate samples were used for each analysis. Moisture content was determined using a Galenkamp oven by allowing hot air circulate over a known quantity of the eTDLM inside the oven. Ash was determined by incinerating known weights of triplicate eTDLM samples at $550{ }^{\circ} \mathrm{C}$ in a Gallenkamp muffle furnace. Protein $(\mathrm{N} \times 6.25)$ was determined by the Micro Kjeldahl method. Crude fiber was determined after digesting a known weight of fat-free sample in refluxing $1.25 \%$ sulfuric acid and $1.25 \%$ sodium hydroxide. Crude fat was determined by exhaustively extracting a known weight of sample in petroleum ether at boiling point between $40{ }^{\circ} \mathrm{C}$ and $60{ }^{\circ} \mathrm{C}$ in a soxhlet extractor. The nitrogen free extract (carbohydrate) content was determined by the difference between the total crude protein, crude fiber, ash and fat from the total dry weight $(100 \mathrm{~g})$ of the eTDLM samples.

\section{Determination of functional properties of ensiled Tithonia diversifolia leaf meal}

The protein solubility (PS) of this product was determined as described by Oshodi and Aletor (1993). The water absorption capacity (WAC) and fat emulsion stability (FES) were determined by the procedure of Beuchat (1977). The fat absorption capacity (FAC) was determined as described by Sosulski (1962). Least gelation concentration (LGC), foaming capacity (FC) and foaming stability (FS) of the product were determined using the techniques of Coffman and Garcia (1977).

\section{Data analysis}

All data were means of duplicate determinations, using simple descriptive analysis. Data were expressed as means \pm standard deviation of duplicate measurements using SPSS 11.0 for Windows (SPSS Inc., Chicago IL, USA).

\section{RESULTS}

\section{Proximate composition}

Proximate composition of ensiled Tithonia diversifolia leaf meal (eTDLM) is presented in Table 1 . The crude protein value averaged $20.0 \% \pm 3.61$. The crude fiber content was $19.0 \% \pm 0.01$ and ether extract/fat content averaged $4.0 \% \pm 0.05$. The ash content was relatively high with an average of $16.7 \% \pm 0.01$ and the nitrogen free extract (soluble carbohydrates) was also relatively high with an average value of $26.0 \% \pm 0.01$. Moisture content averaged $11.8 \% \pm 0.01$.

\section{Functional properties}

Some determined functional properties are presented in Table 2. The water absorption capacity (WAC) of the leaf meal averaged $310.0 \% \pm 1.0$ while the fat (oil) absorption capacity (FAC) in the eTDLM was $354.5 \% \pm 0.1$. The mean fat emulsion capacity (FEC) and fat emulsion stability (FES) of the eTDLM were $42.5 \% \pm 0.07$ and $57.5 \% \pm 0.1$, respectively. The bulk density had an average value of $0.8 \mathrm{~g} / \mathrm{ml}$. The mean values for foaming capacity (FC), foaming stability (FS) and that of least gelation concentration (LGC) of eTDLM were $11.0 \% \pm 0.07,3.0 \mathrm{~cm} \pm 0.7$ and $8.0 \% \pm 5.7$, respectively.

The protein solubility profile of the ensiled Tithonia diversifolia leaf meal as a function of $\mathrm{pH}$ is shown in Figure 1.

The leaf meal showed moderate and stable solubility at both alkaline and acidic media and minimum solubility (isoelectric point) for the leaf meal was reached at between 3 and $5 \mathrm{pH}$ levels. 
Table 1: Proximate composition of ensiled Tithonia diversifolia, eTDLM.

\begin{tabular}{lc}
\hline ETDLM & (\%) Composition \\
\hline Crude Protein & $20.0 \pm 3.61$ \\
Crude Fiber & $19.0 \pm 0.01$ \\
Ether Extract & $4.0 \pm 0.05$ \\
Ash & $16.7 \pm 0.01$ \\
Nitrogen Free Extract & $26.0 \pm 0.01$ \\
Moisture Content & $11.8 \pm 0.01$ \\
\hline
\end{tabular}

Means are for duplicate determination $n=2$

Table 2: Some functional properties of ensiled Tithonia diversifolia leaf meal, eTDLM.

\begin{tabular}{lc}
\hline ETDLM & Composition \\
\hline Water absorption capacity, \% & $310.0 \pm 7.07$ \\
Fat absorption capacity, \% & $354.5 \pm 0.1$ \\
Fat emulsion capacity, \% & $42.5 \pm 0.3$ \\
Fat emulsion stability, \% & $57.5 \pm 0.3$ \\
Foaming capacity, \% & $11.0 \pm 0.07$ \\
Foaming stability (after 30mins, cm) & $3.0 \pm 0.7$ \\
Least gelation concentration, \% & $8.0 \pm 5.7$ \\
Bulk density, g/ml & $0.8 \pm 0.1$ \\
\hline Means are for duplicate determination, $n=2$ &
\end{tabular}

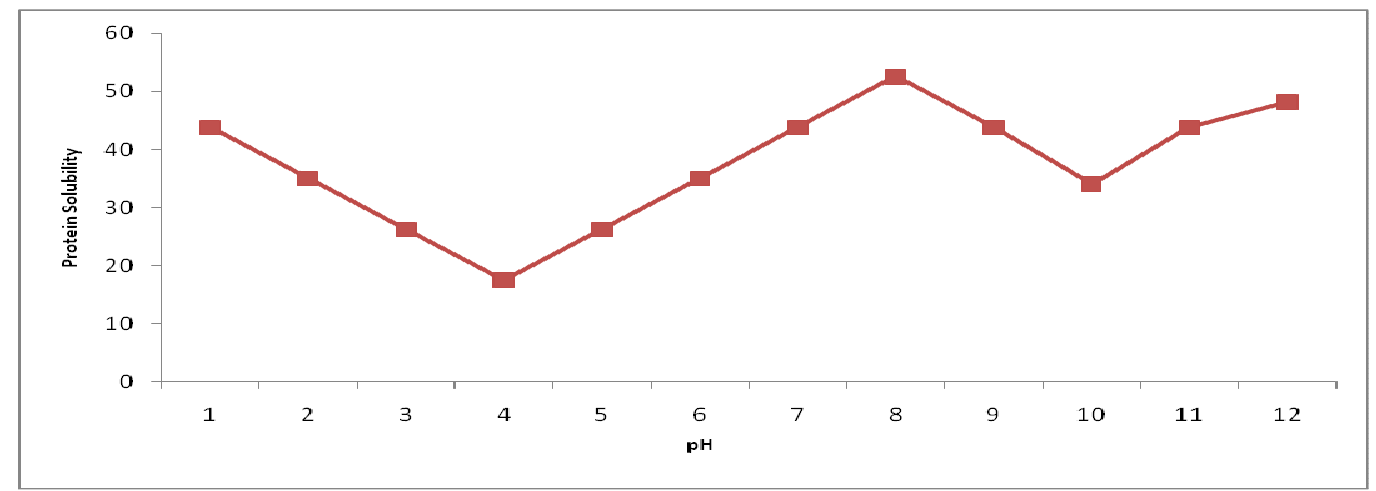

Figure 1: Protein solubility curve of ensiled Tithonia diversifolia leaf meal, eTDLM. 


\section{DISCUSSION}

Proximate composition of ensiled Tithonia diversifolia leaf meal, eTDLM

The proximate composition of eTDLM as obtained in this study underscored its importance as a potential food resource and protein supplement. For instance, the mean crude protein content at $20.0 \% \pm 3.61$ was relatively high although not as high as those reported for most tropical legumes and vegetables (Aletor and Adeogun, 1995; Fasuyi, 2005) but almost within the same range with Talinum triangulare leaf meal with crude protein of $19.9 \% \pm 3.8$ (Fasuyi, 2005) and palm kernel cake of $14.5-19.6 \%$ crude protein (Alimon and Hair-Bejo, 1995).

The eTDLM crude fiber content of $19.0 \% \pm 0.01$ was higher than those reported for Telfaira occidentalis leaf meal at $12.7 \% \pm 4.2$ (Fasuyi, 2005) and Amaranthus cruentus leaf meal at $8.8 \% \pm 3.1$ (Fasuyi, 2005). High fibre content may be an advantage in human nutrition since an inverse relationship exists between fibre consumption and the risk to coronary heart disease and several types of cancer (Lattimer and Haub, 2010).

Ether extract value at $4.0 \% \pm 0.5$ was relatively low but almost within the range reported for Amaranthus cruentus at 5.4\% \pm 3.2 (Fasuyi, 2005). The ash content was relatively high with value of $16.7 \% \pm 0.0 .1$. However, this value was not as high as those reported for Telfaira occidentalis at $19.9 \% \pm 6.2$ and Talinum triangulare at $19.4 \% \pm 3.0$ (Fasuyi, 2005).

The nitrogen free extracts (soluble carbohydrates) was also relatively high with value of $26.0 \% \pm 0.1$. This value was surprisingly higher than value reported for Talinum triangulare at $19.7 \% \pm 0.3$ (Fasuyi, 2005) and cassava leaf protein concentrate at 15.9\% \pm 5.2 (Fasuyi and Aletor, 2005).

\section{Functional properties of ensiled Tithonia diversifolia leaf meal, eTDLM}

The water absorption capacity (WAC) at $310.0 \% \pm 7.07$ was higher than $130 \%$ reported for soya bean (Lin et al., 1974), $134 \%$ reported for African yam bean (Adeyeye et al., 1995) but comparable with $303.33 \%$ and $306.67 \mathrm{ml} \mathrm{H}_{2} \mathrm{O} / 100 \mathrm{~g}$ reported for Barberton and Ashford cultivars of defatted groundnut seed cake, respectively (Fekria et al., 2012).

The fat (oil) absorption capacity (FAC) for eTDLM was $354.5 \% \pm 0.1$ in this study. Hydration/rehydration is the first and perhaps the most critical step in imparting desirable functional properties to proteins in a food system (Fekria et al., 2012). Interactions of water and oil with flours are extremely important in food systems because of their effects on the flavour and texture of foods. Intrinsic factors affecting water-binding properties of food flours with relatively high protein contents include amino acid composition, protein conformation and surface polarity/hydrophobicity. The capacity of protein to absorb water and oil is determined by its polar and non-polar amino acids composition (Sathes et al., 1981). Fat (oil) absorption is mainly attributed to the physical entrapment of oil. It is also related to the number of non-polar side chains on protein that bind hydrocarbon chains on the fatty acids.

The water absorption capacity determines the energy and nutrient dense of a food and it measures the maximum amount of water the material can take up and retain. The high prevalence of protein-energy malnutrition in many developing countries has been attributed to low-dense energy and other important nutrient intake. The main factor attributed to the relatively high WAC value of eTDLM was the presence of different hydrophilic carbohydrates and proteins (due to the hydrophilic amino acids).

Fat (oil) absorption capacity of ensiled Tithonia diversifolia leaf meal with a mean value of $354.54 \% \pm 0.01$ was appreciably higher than those reported for soya and sunflower flour at $84.4 \%$ and $207 \%$, respectively (Lin et al., 1974). Fat absorption has been recognised as an important 
functional property for food product ingredients because it improves flavour retention and the sensation produced in the mouth (Martinez-Flores et al., 2006). The values for the fat emulsion capacity and emulsion stability of eTDLM were $42.50 \% \pm 0.3$ and $57.50 \% \pm 0.3$, respectively and were higher than the $11.7 \%$ and $18 \%$ reported for wheat and soya, respectively (McWatters and Cherry, 1977).

Fat emulsion capacity FEC and fat emulsion stability FES are both important attributes of additives for the stabilization of fat emulsion in the production of food such as sausages, soup and cakes. The ability of protein to aid the formation and stabilization of emulsions is important in many applications including mayonnaise, milk, comminuted meats and salad dressings (Kinsella et al., 1985; Adeyeye et al., 1995).

The foaming capacity (FC) value of eTDLM at $11.0 \% \pm 0.7$ was considerably lower than those of soya flour at $70 \%$ and sunflower flour at $230 \%$ (Lin et al., 1974), soybean and peanut at $110 \%$ and $100 \%$, respectively (McWatters and Cherry, 1977) but higher than 4.2 and $4.0 \mathrm{ml} / 100 \mathrm{ml}$ obtained for Barberton and Ashford cultivars of defatted groundnut seed cake flour, respectively (Fekria et al., 2012).

The foaming stability of eTDLM at $3.0 \pm 0.7$ was also lower than $54.2 \%+0.3$ for cashew nut and most other legume flours (Lin et al., 1974). Foaming stability is an important determinant of the suitability of a whipping agent in food system. The foaming capacity of a protein refers to the amount of interfacial area that can be created by the protein and foam stability (FS) refers to the ability of protein to stabilize against gravitational and mechanical stresses. These two parameters are a function of the type of protein, $\mathrm{pH}$, processing methods, viscosity and surface tension (Fekria et al., 2012).

The least gelation concentration of $8.0 \%$ obtained for ensiled TDLM was lower than $14 \% \quad(\mathrm{w} / \mathrm{v})$ reported for lupin seed proteins (Sathe et al., 1981),12\% for pigeon pea (Sathe et al., 1984), 14\% (w/v) for lupin flour (Oshodi and Ekperigin, 1989) and considerably lower than $36 \%$ reported for fluted pumpkin (Fagbemi and Oshodi, 1991) but higher than $6 \%$ reported for defatted sesame seed (Inyang and Nwadimkpa, 1992). Protein gel formation provides the matrix for holding water, flavours, sugar and ingredients hence it is an important consideration in food product development. The lower LGC, the better is the gelating ability of the protein ingredient (Akintayo et al., 1999). High gelation value of a food would then imply that the diet would require more energy consumption to cook and hence the gel strength of the diets would be weak and undesirable (Enujiugha, 2006).

The moderate LGC value of eTDLM may be ascribed to the ratios of nutrient composition such as proteins, carbohydrates and lipids. Gelling capacity is very useful in food systems such as puddings and sauces that require thickening and gelling (Ma et al., 2011). Protein conformations, disulphide linkages, hydrophobicity are all known to play significant roles in gelation. The LGC value of $8.0 \%$ obtained for eTDLM is an indication of the potential use of eTDLM as confectionary products. The present results suggest clearly that eTDLM may be useful in the production of curd, or as an addition to other materials for gel formation in food products.

The eTDLM had fat emulsion capacity (FEC) value of $42.5 \% \pm 0.03$ which was higher than FEC values of $24.5 \mathrm{~g} / \mathrm{g}$ for peanut flour (Singh and Singh, 1991), 28.33\% and $22.90 \%$ for Barberton and Ashford cultivars of defatted groundnut cake flour, respectively.

The fat emulsion stability (FES) value of $57.5 \% \pm 0.30$ obtained for eTDLM was also higher than $14.0 \%$ and $11.4 \%$ for the groundnut cultivars, respectively ((Fekria et al., 2012). The emulsifying properties are usually attributed to the flexibility of solutes and exposure of hydrophobic domains (Fekria et al., 2012). Food emulsions are thermodynamically unstable mixtures of 
immiscible liquids. Emulsifying capacity is important if the protein concentrate is to be used in products such as salad dressings and mayonnaise (Martinez-Flore et al., 2006).

Flour with good emulsion capacities will be useful in the preparation of comminuted meat products and analogs (Okoye et al., 2008) and also in the formation and stability of emulsion in food systems such as salad dressing (Fekria et al., 2012). The capacity of proteins to enhance the formation and stabilization of emulsion is important for many applications in cakes, coffee whiteners, and frozen desserts (Elkhalifa and Bernhardt, 2010). In these products varying emulsifying and stabilizing capacities are required because of different compositions and stresses to which these products are subjected (Elkhalifa and Bernhardt, 2010). The relatively high FEC and FES values of eTDLM qualify it to be considered as a potential emulsion forming and stabilizing agent in the food system.

The bulk density of $0.8 \mathrm{~g} / \mathrm{ml}$ obtained for eTDLM is higher than the values obtained for defatted groundnut seed cake flour of Barberton and Ashford cultivars (Fekria et al., 2012) and also higher than values reported for most legumes such as field pea (0.541-0.562 $\mathrm{g} / \mathrm{ml}$ ) and pigeon pea at $0.471-0.467 \mathrm{~g} / \mathrm{ml}$ (Kaur et al., 2006). This value is also higher than $0.54-0.57 \mathrm{~g} / \mathrm{ml}$ reported for chickpea flours (Kaur and Singh, 2005). Higher bulk density is desirable as it helps to reduce the paste thickness which is an important factor in convalescent and child feeding. The eTDLM could be useful in food/feed formulation as supplementary feeding for children.

The protein solubility profile of the ensiled Tithonia diversifolia leaf meal as a function of $\mathrm{pH}$ (Figure 1) indicates its high stability at both alkaline and acidic media with minimum solubility (isoelectric point) at between 3 and $5 \mathrm{pH}$ levels. The solubility curve agrees with earlier work carried out by Fasuyi and Aletor (2005) on cassava leaf meal and leaf protein concentrates and other works on African yam bean flower (Adeyeye et al., 1995).
The solubility pattern indicates that eTDLM can be useful in the formation of both acidic and alkaline foods such as protein rich carbonated beverages.

\section{Conclusion}

The empirical data obtained from proximate and functional properties of ensiled Tithonia diversifolia leaf meal is a clear indication of the nutritional potentials of the plant product as probable alternative feed ingredient, particularly for protein supplementation in monogastric feed formulation. Furthermore, the high oil and water absorption capacities of eTDLM would enhance its desirability for use in some foods such as meats, sausages, breads and cakes. The relative moderate bulk density may be an advantage in weaning food.

\section{REFERENCES}

Adeyeye EI, Oshodi AA, Ipinmoroti KO. 1995. Functional properties of some varieties of African yam bean (Sphenostylis stenocarpa) flour II. International Journal of Food Sciences and Nutrition, 45: 115-126.

Akintayo ET, Oshodi AA, Esuoso KO. 1999. Effects of $\mathrm{NaCl}$ ionic strength and $\mathrm{pH}$ on the foaming and gelation of pigeon pea (Cajanus cajan) protein concentrates. Food Chemistry, 66: 51-56.

Aletor VA, Adeogun OA. 1995. Nutrients and anti-nutrients components of some Tropical leafy vegetables. Food Chemistry, 54: 375-379.

AOAC (Association of Official Analytical Chemists). 2010. Official Methods of Analysis $\left(18^{\text {th }} \mathrm{edn}\right)$. AOAC.

Beuchat LR. 1977. Functional and electrophoretic characteristics of succinylated peanut flour protein. Journal of Agricultural Food Chemistry, 25: 258261.

Coffmann CW, Garcia VV. 1977. Functional properties and amino acid Content of a Protein isolate from mung bean flour. Journal of Food Technology, 12: 473. 
Elkhalifa AEO, Bernhardt R. 2010. Influence of grain germination on functional properties of sorghum flour. Food Chemistry, 12: 387-392.

Enujiugha VN. 2006. Supplementation of ogi, a maize based infant weaning food, with

African oil bean (Pentaclethra macrophylla Benth) seed. Journal of Food Agriculture and Environment, 4(2): 34-38.

Fagbemi HM, Oshodi AA. 1991. Chemical composition and functional Properties of fullfat fluted pumpkin seed flour (Telfairia occidentalis). Nigerian Food Journal, 9: 26-32.

Fasuyi AO, Aletor VA. 2005. Varietal composition and functional Properties of cassava (Manihot esculenta Crantz) leaf meal and leaf protein concentrates. Pakistan Journal of Nutrition, 4(1): 4349.

Fasuyi AO, Dairo FAS, Ibitayo FJ. 2010. Ensiling wild sunflower (Tithonia diversifolia) leaves with sugar cane molasses. Livestock Research for Rural Development, 22(3). www.lrrd.org/lrrd22/ fasu22042.htm

Fekria AM, Isam AMA, Suha OA, Elfadil EB. 2012. Nutritional and functional characterization of defatted seed cake flour of two Sudanese groundnut (Arachis hypogaea) cultivas. International Food Research Journal, 19(2): 629-637.

Inyang UE, Nwadimkpa CU. 1992. Functional properties of dehulled sesame (Sesamum indicum L.) seed flour. Journal of American Oil Chemists Society, 69: 819822.

Kaur M, Singh N. 2005. Studies on functional, thermal and pasting properties of flours from different chickpea (Cicer arietinum L.) cultivars. Food Chemistry, 91: 403411.

Kaur M, Sandhu KS, Singh N. 2006. Comparative study of the functional, thermal and pasting properties of flours from different field pea (Pisum sativum L.) and pigeon pea (Cajanus cajan L.) cultivars. Food Chemistry, 104: 259-267.
Kinsella JE, Damodaran S, German B. 1985. Physico-Chemical and Functional Properties of Oilseed Protein with Emphasis on Protein (vol. 5). Academic Press: Orlando.

Lattimer JM, Haub MD. 2010. Effects of dietary fibre and its components on metabolic health. Nutrients, 2: 12661289.

Lin MJY, Humbert ES, Sosulki FW. 1974. Certain functional properties of sunflower meal product. Journal of Food Science, 39: 368-370.

Ma Z, Boye JI, Simpson BK, Prasher SO, Monpetit D, Malcomson LD. 2011. Thermal processing effects on the functional properties and microstructure of lentil, chickpea, and pea flours. Food Research International, doi: 10.1016/j.foodnes.2010.12.017.

Martinez-Flores HE, Barrera ES, GarnicaRomo MG, Penagos CJC, Saavedra JP, Macazaga-Alvarez R. 2006. Functional characteristics of protein flaxseed concentrate obtained applying a response surface methodology. Journal of Food Science, 7(8): 495-498.

McWatter KH, Cherry JP. 1977. Emulsification, foaming and protein solubility properties of defatted soya bean, peanut, field pea and pecan flour. Journal of Food Science, 42: 1444-1447.

Olayeni TB, Farinu GO, Togun VA, Adedeji OS, Aderinola AO. 2006. Performance and hematological characteristics of weaner pigs fed wild sunflower (Tithonia diversifolia Hemsel A. Grey) leaf meal. Journal of Animal and Veterinary Advances, 5(6): 499-502.

Okoye JI, Nkwocha AC, Agbo AO. 2008. Chemical composition and functional properties of kidney bean/wheat flour blends. Continental Journal of Food Science and Technology, 2: 27-32.

Oshodi AA, Aletor VA. 1993. Functional properties of haemagglutinins (lectins) extracted from three edible varieties of lima beans (Phaseolus lunatus). 
International Journal of Food Science and Nutrition, 44: 133-136.

Oshodi AA, Ekperigin MM. 1989. Functional properties of pigein pea (Cajanus cajan) flour. Food Chemistry, 34: 187-191.

Pham SyTiep, Nguyen Van Luc, TrnhQuangTuyen, Nguyen Manh Hung and Tran van Tu. 2006. Study on the use of Alocasia macrorrhiza (roots and leaves) in diets for crossbred growing pigs under mountainous village conditions in northern Vietnam. Workshop-Seminar "Forages for Pigs and Rabbits" MEKARN-CelAgrid, Phnom Penh, Cambodia, 22-24 August, 2006. Article \# 11. http://www.mekarn.org/ proprf/tiep.htm
Sathe SK, Deshpande SS, Salunke DK. 1981. Functional properties of lipin seed (Lipinus mutabilis) protein and protein concentrates. Foods Science, 47: 491497.

Sathe SK, Deshpande SS, Salunkhe DK. 1984. Functional properties of winged bean (Psophocarpus tetragonolobus L. DC) proteins. Journal of Food Science, 47: 503-509.

Singh U, Singh B. 1991. Functional properties of sorghum - peanut composite flour. Cereal Chemistry, 68: 460 - 463.

Sosulski FW 1962.The centrifuge method for determining flour absorption in hard red spring wheat. Cereal Chemistry, 39: 344350. 